\title{
Corporate attributes and market capitalization. Evidence from Bangladesh
}

\author{
Md. Shamimul, Hasan \\ Normah, Omar \\ Syed Zabid, Hossain \\ - received: 27 august 2014 \\ - ACCePTED: 28 NOVEMBER 2014
}

\begin{abstract}
This study explores the influence of corporate attributes on market capitalization, based on the potential relationships between corporate attributes, corporate disclosure, and market capitalization. The study focused on non-financial listed companies in Bangladesh and uncovered several significant influences of corporate attributes, such as asset size, turnover, shareholders, and internationality, on market capitalization. This contribution provides new insights into corporate attributes and market capitalization, and suggests that existing and potential investors should assess corporate attributes while making investment decisions.
\end{abstract}

\section{Keywords:}

Market capitalization, Corporate attributes, Asset size, Turnover, Bangladesh.

JEL classification:

C12, C30, G10, M41, N25.

Dr. Md. Shamimul H., $\varangle$ PostDoctoral Scholar,Accounting Research Institute (ARI), UniversitiTeknologi MARA (UiTM), Shah Alam, Malaysia. Email:dr.mdshamimulhasan@rocketmail.com.

Dr. Normah, O., Director, Accounting Research Institute (ARI), Universiti Teknologi MARA (UiTM), Shah Alam, Malaysia.

Email:normah645@salam.uitm.edu.my.

Dr. Syed Zabid, H., Professor of Finance, School of Business, Tecnológico de Monterrey, Guadalajara, México. Email: syed6205@gmail.com. 


\title{
Atributos corporativos y capitalización de mercado. Evidencia desde Bangladesh
}

\author{
Md. Shamimul, Hasan \\ Normah, Omar \\ Syed Zabid, Hossain
}

\section{Resumen}

Este artículo analiza el impacto de una selección de atributos corporativos en la capitalización de mercado puesto que dichos atributos corporativos, la divulgación de la información corporativa y la capitalización de mercado podrían estar relacionados. En el estudio llevado a cabo en Bangladesh, utilizando empresas no financieras cotizadas, se ha detectado que el volumen de activos, la cifra de negocios, el número de accionistas y el grado de internacionalización son atributos corporativos que ejercen una influencia significativa en la capitalización de mercado de dichas empresas. Este hecho arroja nueva luz sobre la relación atributos corporativos-capitalización de mercado en Bangladesh, y sugiere que tanto los inversores actuales como los potenciales deberían poner atención a los anteriores atributos corporativos a la hora de tomar sus decisiones de inversión.

\section{Palabras clave:}

Capitalización de mercado, atributos corporativos, volumen de activos, cifra de negocios, Bangladesh. 


\section{Introduction}

Market capitalization is one of the most important economic indicators that demonstrate the significance of corporate reputation in the stock market. The stock market is highly sensitive and stock price frequently changes in response to both financial as well as non-financial information. Information relating to the company, the industry, the market and also the economy is reflected in the share price. Company management alone is responsible for producing company information which is transmitted to the stakeholders in various ways such as annual reports, electronic media, print media, websites, press conferences and so on. All this information can immediately influence share price (both positively and negatively).If the information is positive for the company then share price will go up and vice-versa.

Every company has its own vision, structure, features, strengths, work plans and strategies, which differentiate it from other companies. The characteristics of the companies sampled in this study differ from one another in terms of size, the nature of business, capital structure, management style and structure, and profitability. Furthermore, the auditors and accountants of these organizations are not equally qualified, and some companies even have different accounting periods. They also differ in terms of market capitalization, turnover, number of shareholders and international exposure. These disparities between corporate attributes may influence their market capitalization.

The Bangladesh capital market experienced two bubble-and-burst episodes - one in 1996, the other in 2011 (Hasan et al., 2014). The bubble in 2011 was created by increasing the value of assets of relevant companies. The probe committee (2011) reported that company assets increased by $3,472 \%$ in the name of revaluation, which goes against accounting principles (Hasan et al., 2014). The markets were highly inflated by means of false reporting and providing misinformation in order to achieve desired goals. This issue suggested a relationship between corporate attributes and market capitalization. In light of this issue, we refer to the Agency Theory, which argues that there is a conflict of interest between principals (shareholders) and agents (management). Shareholders are the real owners and agents are office-bearers. The office-bearers (agents) have the ability to influence market capitalization by passing on information regarding corporate attributes.

There are many studies on corporate attributes including Alam (2007), Barako (2007), Ahmed (2009), and Hasan and Hossain (2013). These researchers studied the impact of corporate attributes on corporate disclosure - disclosures which can 
influence the share price on the capital market. However, these studies did not assess the impact of corporate attributes on market capitalization. This is very important, especially for Bangladesh, where most investors have little knowledge of the influence of company, industry, market and economy characteristics on share price. This study bridges the current research gap by examining the influence of corporate attributes on market capitalization, finding a linear relationship among corporate attributes, disclosure and market capitalization. Corporate attributes influence disclosure and disclosure influences market capitalization, and so this study can be considered as an extended version of a corporate attributes study. This study also aims to contribute to the existing literature and to help regulators, stock brokers, individual investors, institutional investors, professional bodies, reporters, researchers, analysts, academics and other interest groups be aware if corporate attributes provided by the companies have been manipulated to achieve their desired goals.

Hence, the key objective of this study is to examine the influence of selected corporate attributes, such as asset size, turnover, shareholders and internationality on corporate market capitalization.

The next section (Section 2) presents the pertinent literature review, section 3 is devoted to the methodology and data gathered, section 4 includes the results and the discussion, and Section 5 concludes this study.

\section{Literature review}

The study of corporate attributes is one of the most popular research areas in accounting research, with a large body of literature already existing, mainly pertaining to disclosure issues. Company characteristics have been used widely in the study of disclosure in accounting literature. Such studies take corporate attributes as independent variables and corporate disclosure as dependent variables in their models.

Researchers studied the influence of corporate attributes on issues such as the aggregate disclosure index (Alam, 2007; Ahmad, 2009; and Hasan and Hossain, 2013), the voluntary disclosure index (Eng and Mak, 2003; Prencipe, 2004; Barako, 2007; and Nalikka, 2012), the statuary disclosure index (Patton and Zelenka, 1997; Razzaque, 2004; and Akhtaruddin, 2005), extensive disclosures (latridis, 2008), the environmental disclosure index (Osazuwa et al., 2013; and Alikhani and Maranjory, 2013), and the corporate social responsibility disclosure index (Tamoi et al., 2007; Nazli, 2007; and Rouf, 2011). In addition to the above, some authors have tested 
the association between corporate attributes and timeliness of corporate reporting (Courtis, 1976; Davies and Whittred, 1980; and lyoha, 2012).

However, previous research did not focus on the subsequent impact of corporate attributes on the stock market. The effects of disclosure are felt in the capital market immediately and the market capitalization moves up for positive information and down for negative information. As the relation between disclosure and market capitalization is clear, we believe that corporate attributes may also have an effect on market capitalization due to their significant relationship with corporate disclosure. The limitation of previous studies is a lack of focus on the impact of corporate disclosures on the stock market, where one of the important objectives of producing disclosures is to provide information for the capital market. Therefore, we need to examine whether market capitalization is related to corporate attributes. This study strives to fill this research gap by building an empirical model to establish whether market capitalization is related to a number of company-specific characteristics using regression analysis. In other words, the present research is designed to form a graphical presentation to connect the present research with previous studies. Figure 1 clearly shows that in the past, researchers focused on the influence of corporate attributes on corporate disclosure. In the diagram, the wave of corporate disclosures influences the capital market i.e., market capitalization. The current study extends that research by examining the influence of corporate attributes on market capitalization.

Figure 1. The Concept of the present research

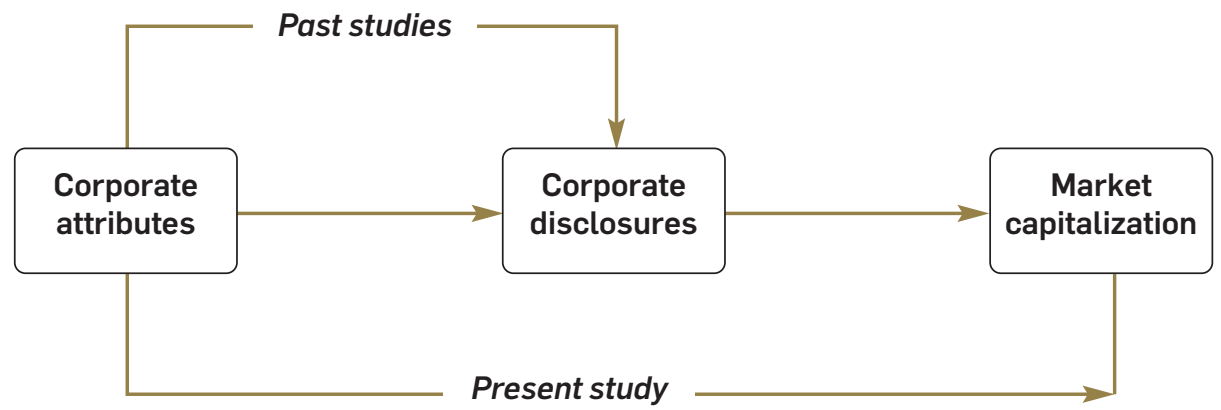




\section{Data and methods}

\subsection{Data}

Of the 155 non-financial companies listed on the Dhaka Stock Exchange (DSE), the largest capital market in Bangladesh, 68 were taken as a sample data set for the current study, based on the availability of corporate annual reports for 20102011 (see Appendix). The sample size represents 44\% of the population and so allows us to generalize the findings of this study. Market capitalization and company age (year of listing) data are collected from the DSE and data for all other variables are extracted from a survey of annual reports of sampled companies.

\subsection{Methods}

In order to estimate the effect of corporate attributes on the market value of equity or market capitalization ( $M C$ ) of sampled companies, this has been selected as the dependent variable, while asset size $(A S)$, turnover $(T R)$, number of shareholders $(N S)$, and internationality $(I Y)$ have been selected as explanatory variables. Leverage $(L E)$, company age $(C A)$, and reputation of audit firm $(R A)$ have been selected as control variables for our empirical model. We then tested if the effect of the above explanatory variables on $M C$ is null or significantly different from zero (the nullity of these effects constitutes the hypotheses of the model). The linear regression model is as follows:

$$
M C_{i}=\alpha+\beta_{1} A S_{i}+\beta_{2} T R_{i}+\beta_{3} N S_{i}+\beta_{4} I Y_{i}+\beta_{5} L E_{i}+\beta_{6} C A_{i}+\beta_{7} R A_{i}+\varepsilon_{i}
$$

The definition and measurement of the above variables and the range of their values are presented in Table 1. Below we provide a brief explanation of the dependent and independent variables included in the model.

\section{Market capitalization}

Market capitalization is the market value of the equity of a firm. It is a dynamic economic indicator which indicates the demand for company stock in the capital market. Higher market capitalization means higher demand for stock. The movement of market capitalization depends on the movement of investors, and movement of investors depends on information. Information regarding corporate attributes is often reflected in changing stock price in the capital market.

\section{Asset size}

Total assets comprise fixed assets as well as current assets. According to the accrual method of accounting, non-cash transactions are recorded in account books. Two international accounting standard boards, the Financial Accounting Standard Board 
(FASB) and International Accounting Standard Board (IASB), issue accounting standards; FASB for the USA and IASB for the rest of the world. Assets can be valued by two methods: the cost model or the revaluation model as per IAS-16 Property, Plant and Equipment. A key difference between these two models is that the cost model allows only decreases in the values of assets compared with historical costs whereas the revaluation model may result in increased asset values relative to historical costs. While the IASB allows the use of either the revaluation model or the cost model, the revaluation model is not allowed under the rules of Generally Accepted Accounting Principles (GAAP) in the USA. Most Bangladeshi companies use the revaluation method to increase share price in the market and to exploit shareholders (Inquiry Report, 2011).

\section{Turnover}

Corporate turnover is considered as a company's principal strength, as high turnover indicates good performance and vice-versa. Turnover includes both cash sales and credit sales according to the accrual method of accounting. The survival of a company depends on its turnover, and higher turnover allows a company to access financial services. Company management can therefore enhance their chances of accessing financial services by manipulating turnover figures. Information on high turnover may therefore also influence market capitalization.

\section{Number of shareholders}

The number of company shareholders reflects information on the spread of shares, which is an important factor to potential investors and therefore influences market capitalization. More shareholders means a wider spread of shares and more public participation whereas the opposite is true with fewer shareholders. Furthermore, a smaller number of shareholders can form a syndicate in order to manipulate the share price by creating an artificial demand in the market.

\section{Internationality}

Foreign ownership within the ownership structure is treated as an indication of the internationality of the firm in this study. Foreign shareholders are generally accepted to be more knowledgeable about reporting, business strategies, corporate governance, and future potentials. Therefore, the presence of foreign shareholders in the ownership structure creates a positive image for the company. Companies with foreign ownership also disclose a greater amount of reliable information which ultimately affects market capitalization. Potential shareholders are known to buy shares on the basis of foreign ownership alone, and so it can create a demand for the stock in the capital market. According to the price mechanism theory of economics, the relationship between demand and price is positive, i.e., if demand goes up then price goes up. The international reputation of a company might therefore have an impact on market capitalization. 
Table 1.Definition, measurement, and range of values of the dependent, independent and control variables

\begin{tabular}{|c|c|c|c|}
\hline Variables & Definition & Measurement & Range of values \\
\hline \multicolumn{4}{|l|}{ Dependent variable } \\
\hline $\begin{array}{l}\text { Market capitalization } \\
(\mathrm{MC})\end{array}$ & $\begin{array}{l}\text { Market value of equity of the } \\
\text { sampled companies. }\end{array}$ & $\begin{array}{l}\text { Closing share price multiplied } \\
\text { by outstanding number of } \\
\text { ordinary shares. }\end{array}$ & Any positive value \\
\hline
\end{tabular}

\section{Independent variables}

\begin{tabular}{|c|c|c|c|}
\hline Asset size (AS) & $\begin{array}{l}\text { Total assets of sampled } \\
\text { companies. }\end{array}$ & $\begin{array}{l}\text { Sum of non-current assets } \\
\text { and current assets }\end{array}$ & Any positive value \\
\hline Turnover (TR) & $\begin{array}{l}\text { Total turnover of sampled } \\
\text { companies during study } \\
\text { period. }\end{array}$ & $\begin{array}{l}\text { Sum of credit sales and cash } \\
\text { sales of sampled companies. }\end{array}$ & Any positive value \\
\hline $\begin{array}{l}\text { Number of } \\
\text { shareholders (NS) }\end{array}$ & $\begin{array}{l}\text { Number of shareholders of } \\
\text { sampled companies. }\end{array}$ & $\begin{array}{l}\text { Aggregate number of share- } \\
\text { holders }\end{array}$ & $227 \leq$ \\
\hline $\begin{array}{l}\text { Internationality } \\
\text { (IY) }\end{array}$ & $\begin{array}{l}\text { Foreign ownership in the } \\
\text { ownership structure }\end{array}$ & $\begin{array}{l}\text { Takes a value of " } 1 \text { " for } \\
\text { foreign ownership and " } 0 \text { " } \\
\text { otherwise. }\end{array}$ & 0,1 \\
\hline
\end{tabular}

\section{Control variables}

\begin{tabular}{|c|c|c|c|}
\hline Leverage (LE) & $\begin{array}{l}\text { Use of long-term debt in fi- } \\
\text { nancing structure of sampled } \\
\text { companies. }\end{array}$ & $\begin{array}{l}\text { Takes a value of " } 1 \text { " for long- } \\
\text { term debt and " } 0 \text { " otherwise. }\end{array}$ & 0,1 \\
\hline Company age (CA) & $\begin{array}{l}\text { Old companies are those list- } \\
\text { ed before the } 1994 \text { Compa- } \\
\text { nies Act and new companies } \\
\text { are those enlisted thereafter. }\end{array}$ & $\begin{array}{l}\text { Takes a value of " } 1 \text { " for old } \\
\text { companies and " } 0 \text { " for new } \\
\text { companies. }\end{array}$ & 0,1 \\
\hline $\begin{array}{l}\text { Reputation of } \\
\text { audit firm (RA) }\end{array}$ & $\begin{array}{l}\text { The international links of } \\
\text { audit firm. }\end{array}$ & $\begin{array}{l}\text { Takes a value of " } 1 \text { " for inter- } \\
\text { national links of audit firm } \\
\text { and " } 0 \text { " otherwise. }\end{array}$ & 0,1 \\
\hline
\end{tabular}

\section{Results and discussion}

The results from Pearson's pairwise product-moment correlation coefficient (Table 2 ), demonstrate that there is no problem of multicollinearity between the explanatory variables. This result confirms the non-existence of linear combinations in the variables included in the model. The highest correlation coefficient is that of asset size and turnover, at 0.845 . The linear correlation is not considered indicating multicollinearity until it exceeds 0.90 (Judge et al., 1985; and Bryman and Cramer, 1997). Thus, the multiple regression analysis proposed can be conducted without removing any variable from the model. 
Table 2. Correlations matrix

\begin{tabular}{|c|c|c|c|c|c|c|c|}
\hline Variables & $A S$ & $T R$ & NS & $I Y$ & $L E$ & $C A$ & $R A$ \\
\hline$A S$ & 1 & & & & & & \\
\hline$T R$ & $.845^{* *}$ & 1 & & & & & \\
\hline NS & $.370^{* *}$ & $.346^{* *}$ & 1 & & & & \\
\hline$I Y$ & 0.237 & 0.21 & -0.018 & 1 & & & \\
\hline$L E$ & 0.028 & 0.153 & 0.182 & 0.098 & 1 & & \\
\hline$C A$ & -0.117 & -0.132 & -0.221 & 0.087 & 0.052 & 1 & \\
\hline$R A$ & $.296^{*}$ & 0.219 & 0.027 & $.266^{*}$ & 0.143 & 0.148 & 1 \\
\hline
\end{tabular}

** Significant at the 0.01 level (2-tailed). *Significant at the 0.05 level (2-tailed).

As for the estimation of the regression model, Table 3 shows that the corporate attributes included in the model explain $84 \%$ of the variation in market capitalization. A significant relationship between market capitalization and the corporate attributes selected is found. More specifically, Table 3 shows that the asset size and turnover have a significant influence on market capitalization at the $1 \%$ level, whereas the number of shareholders and internationality are significant at the $5 \%$ level.

Table 3. Estimates of the coefficients of the Model

\begin{tabular}{cccc}
\hline Predictors & Coefficients & $\boldsymbol{t}$ - Value & $\mathbf{P}$ - Value \\
\hline$A S$ & 0.434 & 3.965 & $0.000^{*}$ \\
\hline$T R$ & 0.437 & 4.123 & $0.000^{*}$ \\
\hline$N S$ & 0.129 & 2.103 & $0.040^{\star *}$ \\
\hline$I Y$ & 0.116 & 2.015 & $0.049^{* *}$ \\
\hline$L E$ & -0.009 & -0.150 & 0.882 \\
\hline$C A$ & 0.039 & 0.682 & 0.498 \\
\hline$R A$ & -0.002 & -0.040 & 0.968 \\
\hline
\end{tabular}

\begin{tabular}{lc}
\hline$R$ & 0.919 \\
\hline$R^{2}$ & 0.844 \\
\hline Adjusted $R^{2}$ & 0.823 \\
\hline F-Value & 40.966 \\
\hline$P$-Value & $0.000^{\star}$ \\
\hline$D F$ Model & 7 \\
\hline$D F$ Error & 53 \\
\hline
\end{tabular}

AS Asset size
TR Turnover
NS Number of shareholders
IY Internationality
LE Leverage
CA Company age
RA Reputation of audit firm
$R^{2} \quad$ The explanatory power of regression equation
** Significant at the 0.01 level (2-tailed).
*Significant at the 0.05 level (2-tailed).


Table 3 also reveals that the most influential corporate attribute is turnover and that, as expected, it has a positive relation with market capitalization. The second most influential corporate attribute is asset size, which, again as expected, has a positive linear relation with market capitalization. This is followed by the number of shareholders, which correlates positively with market capitalization. The least influential of the corporate attributes included in the model is internationality, with the sign of its regression coefficient being, as expected, positive.

First, let us examine turnover. Increased turnover is usually a result of selling goods for either cash or credit, and increased turnover leads to an improved share price. This is a common business phenomenon but corporate management has the unique ability to overstate or understate earnings. Capital market participants should compare previous turnover figures with the latest and judge whether it is abnormal or normal. If the figure is impressive, and therefore could represent an abnormal situation, there is a risk of turnover figure manipulation. The impressive figure (abnormally augmented figure) will push up the share price to reflect the business performance. Therefore, existing as well as potential shareholders should pay careful attention to the turnover figure. Inconsistency in turnover figures may give valuable investment information..

The second most influential attribute, asset size, can be increased either by the purchase of new assets or revaluation of old assets. Unlike the GAAP USA, the International Financial Reporting Standards (IFRS) allows the revaluation of old assets to show the assets at a fair price in the statement of financial position. The 2010-2011 stock market crash was caused by an asset-pricing bubble. The probe committee (2011) found that most of the companies took advantage of the weakness of IAS-16 Property, Plant and Equipment and revalued their assets at a higher rate (the highest was 3,247\%). They did so in order to increase share price in the market instead of showing their assets at a fair price in the statement of financial position.

The number of shareholders has a lower impact than assets size and turnover. More shareholders mean more demand for the shares in short supply, and the gap between demand and supply increases the share price in the market. In such cases, management can influence the shareholders by providing misinformation on earnings, false hope as to the potential of the business, overvaluation of assets, payment of dividends from asset revaluation reserves and the like. Such information can drive up the share price. In the case of a limited number of shareholders, the share price can also be increased by creating an artificial demand through serial trading or syndicating to exploit the shareholders in the market. Therefore, shareholders need to proceed with caution when investing in the share market. 
The lowest degree of (positive) influence on market capitalization of the four corporate attributes selected in the model corresponds to internationality. Foreign investment can be attractive to existing as well as potential shareholders. The presence of foreign ownership within the ownership structure can create a positive image in the capital market. Usually, corporate governance of these firms is comparatively better than those firms without any foreign ownership. Foreign ownership creates a good reputation for a firm which can spread through the stock market very quickly leading to increased share price. This is ethical if the share price increases in response to accurate information, although management can try to hide information to maintain their reputation not only with their foreign partners but also in the capital market, as well as in an attempt to to keep the control of the company in their own hands. Therefore, shareholders must study the ownership structure for foreign investment before making their investment decision.

\section{Conclusion}

This study focused on a new and extended area of corporate attributes literature in accounting research. We believed that corporate attributes might be related to market capitalization, due to their relationship with corporate disclosures and the obvious relationship between disclosures and market capitalization. We then examined whether market capitalization is related to corporate attributes and found a statistically significant relationship between corporate attributes and market capitalization. More specifically, we found that, in Bangladesh, turnover and asset size are significant at the $1 \%$ level, and that the number of shareholders and internationality have a significant influence on market capitalization at the $5 \%$ level. Investors should assess corporate characteristics at the time of investment decision as these characteristics can influence disclosures as well as market capitalization. The study recommends arranging free campaigns, seminars, workshops, and conferences etc. for small investors to educate them on financial and accounting matters in order to protect their interests. To the best of our knowledge, this research is the first study to address the issue of the influence of corporate attributes on market capitalization. Future research may glean more insights into this new area of accounting research.

\section{Acknowledgements}

The researchers gratefully acknowledge the generous financial support of the Accounting Research Institute (ARI) and the Ministry of Education, Government of Malaysia, without which the present study could not have been completed. 


\section{References}

Ahmed, A. (2009). Corporate Attributes and The Exten of Disclosure: A Study of Banking Companies in Bangladesh, International Management Accounting Conference 5, Universiti Kebangsaan Malaysia (UKM), Kuala Lumpur.

Akhtaruddin, M. (2005). Corporate Mandatory Disclosure Practices in Bangladesh, The International Journal of Accounting, 40(4), pp. 399-422.

Alam, J. (2007). Financial disclosure in developing countries with special reference to Bangladesh, Ph.D Dissertation, Ghent University, Belgium.

Alikhani, R. and Maranjory, M. (2013). An investigation on the relationship between social and environmental information disclosure level and firms performance in Iran, International Research Journal of Applied and Basic Sciences, 5(1), pp. 125-128.

Barako, D.G. (2007). Determinants of voluntary disclosures in Kenyan companies annual Reports, African Journal of Business Management, 1(5), pp. 113-128.

Bryman, A.E. and Cramer, D. (1997). Quantitative data analysis with SPSS for Windows: A guide for social scientists, Routledge, New York and London.

Courtis, J.K. (1976). Relationships between timeliness in corporate reporting and corporate attributes, Accounting and Business Research, 7(25), pp. 45-56.

Davies, B. and Whittred, G.P. (1980). The association between selected corporate attributes and timeliness in corporate reporting: further analysis. ABACUS, 16(1), pp. 48-60.

Eng, L.L. and Mark, Y.T. (2003). Corporate governance and voluntary disclosure, Journal of Accounting and Public Policy, 22(4), pp. 325-345.

Hasan, M.S. and Hossain, S.Z. (2013). Corporate attributes and financial disclosures: Bangladesh Experience, ICAN Journal of Accounting \& Finance, 2(1), pp. 31-43.

Hasan, M.S., Hossain, S.Z. and Abdul Rahman, R. (2014). Corporate governance and corporate accruals : the situation in Bangladesh, AESTIMATIO, the IEB International Journal of Finance, 9, pp. 90-111.

Hasan, M.S., Hossain, S.Z. and Abdul Rahman, R. (2014). Corporate accruals practices of listed companies in Bangladesh, European Journal of Economics and Management, 1(1), pp. 17-46.

Iatridis, G. (2008). Accounting disclosure and firms' financial attributes: evidence from the UK, International Review of Financial Analysis, 17, pp. 219-241.

Inquiry Report. (2011). Stock market investigation report, Ministry of Finance, Government of Bangladesh, Dhaka.

Iyoha, F.O. (2012). Company attributes and the timeliness of financial reporting in Nigeria, Business Intelligence Journal, 15(1), pp. 41-49.

Judge, G., Griffiths, W.E., Hill, R.C., Lutkepohl, H. and Lee, T.C. (1985). The theory and practice and econometrics, John Wiley, NewYork.

Nalikka, A. (2012). Essays on information disclosure in company annual reports: evidence from Finland and the United Kingdom, Vaasan Yliopisto, Vaasan, Finland. 
Nazli, A.M.G. (2007). Ownership structure and corporate social responsibility disclosure: some Malaysian evidence, Corporate Governance, 7(3), pp. 251-266.

Osazuwa, N.P., Okoye, F.A. and Izedonmi, F. (2013). Corporate attributes and environmental disclosures of Nigerian quoted firms: an empirical analysis, Research Journal of Social Science and Management, 3(6), pp. 113-129.

Prencipe, A. (2004). Propietary costs and determinants of voluntary segment disclosure: evidence from Italian listed companies, The European Accounting Review, 13(2), pp. 319-340.

Razzaque, S. (2004). Financial reporting and corporate governance in Bangladesh: A study on some manufacturing companies listed in Dhaka Stock Exchange Ltd, Ph. Dissertation, University of Rajshahi, Rajshahi.

Rouf, M.A. (2011). The corporate social responsibility disclosure: A study of listed companies in Bangladesh, Business and Economics Research Journal, 2(3), pp. 19-32.

Tamoi J., Corina, J. and Nero M. (2007). The Current State of Corporate Social Responsibility Among Industrial Companies in Malaysia, Social Responsibility Journal, 3(3), pp. 9-18.

\section{Appendix}

List of sample companies

\begin{tabular}{|c|c|c|c|}
\hline SN & Company Name & SN & Company Name \\
\hline 1 & Rahim Textile & 35 & Ambee Pharma \\
\hline 2 & Samorita Hospitals & 36 & Pama Oil Company \\
\hline 3 & Savar Refractories ltd & 37 & Salvo Chemical Industry Limited \\
\hline 4 & Beach Hatechery ltd & 38 & British American Tobacco \\
\hline 5 & Tallu Spinning Mills & 39 & Eastern Housing Limited \\
\hline 6 & Imam Button & 40 & Bata Shoe Company \\
\hline 7 & Safko Spinning & 41 & National Tea Company Limited \\
\hline 8 & Anlima Yarn Dyeing ltd & 42 & Aziz Pipe \\
\hline 9 & Bangladesh Auto Cars Limited & 43 & Jamuna Oil Company Limited \\
\hline 10 & Eastern Cables & 44 & National Polymer Industries Limited \\
\hline 11 & Atlas Bangladesh Limited & 45 & Quasem Drycells Ltd \\
\hline 12 & Meghna Petrolium Limited & 46 & CMC Kamal Textile Mills Limited \\
\hline 13 & Apex Adelchi Footwear Limited & 47 & Bangladesh Lamps Ltd. \\
\hline 14 & Deshbandhu Polymer Limited & 48 & Metro Spinning Mills Limited \\
\hline 15 & Fine Foods Limited & 49 & MJL Bangladesh Limited \\
\hline 16 & Khulna Power Company Limited & 50 & Aftab automobiles limited \\
\hline 17 & GBB Power Limited & 51 & Square Textiles Limited \\
\hline 18 & Libra Infusion Limited & 52 & Singer Bangladesh Limited \\
\hline 19 & The Dacca Dyieng \&b Manufacturing & 53 & ACI Formulations Limited \\
\hline
\end{tabular}




\begin{tabular}{llll}
\hline 20 & R. N. Spinning Limited & 54 & Prime Textile Spinning Mills Limited \\
\hline 21 & BSRM Steels Limited & 55 & Saiham Textile Mills Limited \\
\hline 22 & Bangladesh Thai Aluminium Ltd. & 56 & H. R. Textile Mills Limited \\
\hline 23 & Keya cosmetics ltd & 57 & Agricultural Marketing Co Ltd \\
\hline 24 & M I Cement Factory Ltd. & 58 & Apex Spinning \& Knitting Mills Limited \\
\hline 25 & Fuwang Foods Ltd. & 59 & Makson Spinning Mills Limited \\
\hline 26 & Pharma Aids Limited & 60 & Malek Spinning Mills Ltd. \\
\hline 27 & Kohinoor Chemical Company & 61 & Jute Spinners Limited \\
\hline 28 & Samata Leather Complex Ltd & 62 & BD COM Limited \\
\hline 29 & Sonali Aansh Industries Limited & 63 & Daffodil Computers Limited \\
\hline 30 & Navana CNG Limited & 64 & United Airways Limited \\
\hline 31 & Grameen Phone & 65 & Standard Ceramic Industries Limited \\
\hline 32 & Dhaka Electric Supply Company Limited & 66 & Beacon Pharma \\
\hline 33 & Titas Gas Transmission and Distribution & 67 & Orion Infusion Ltd. \\
\hline 34 & Square Pharmaceuticals & 68 & Active Fine Chemicals Ltd \\
\hline & & & \\
\hline
\end{tabular}

